\title{
APLIKASI ANALISIS TRANSAKSIONAL BERFOKUS PENGASUHAN ANAK PADA PASANGAN DENGAN MASALAH RELASI PERKAWINAN
}

\author{
Dearisa Surya Yudhantara*® ${ }^{\star}$, Aris Sudiyanto**, Gst Ayu Maharatih ${ }^{\star *}$
}

\begin{abstract}
Abstrak
Masalah relasi pada pasangan dapat mempengaruhi timbulnya masalah pada pengasuhan anak. Orangtua dengan masalah relasi akan menyebabkan gangguan pada pola asuh anak yang akan menyebabkan beberapa maslah pada anak seperti psikopatologi, gangguan perilaku, dan penurunan prestasi akademik. Peneltan ini adalah penelitan kualitatf berbentuk studi kasus dan aplikasi modul psikoterapi analisis transaksional pada pasangan dengan masalah relasi perkawinan berfokus pada pengasuhan anak. Studi ini melibatkan 3 pasangan Pada pelaksanaan psikoterapi analisis transaksional dengan setting terapi pasangan ini, dua klien dapat mengikut hingga selesai, sedangkan satu klien tidak menyelesaikan proses psikoterapi. Terdapat perbaikan pada pola pengasuhan anak pada 2 pasangan klien yang mengikut proses psikoterapi analisis transaksional hingga selesai. Perbaikan pola pengasuhan anak seiring dengan perbaikan relasi pada pasangan. Perbaikan ini berkaitan dengan bertambahnya waktu untuk anak, lebih banyak kasih sayang, dan afeksi kepada anak. Penelitan ini menyimpulkan bahwa aplikasi modul psikoterapi analisis transaksional pada pasangan dengan masalah relasi perkawinan dapat memperbaiki relasi, menambah keintiman pasangan, dan memperbaiki psikopatologi. Perbaikan relasi perkawinan turut memperbaiki pengasuhan anak.
\end{abstract}

Kata Kunci: analisis transaksional, pola asuh anak, psikopatologi, relasi perkawinan.

\section{TRANSACTIONAL ANALYSIS APPLICATION FOCUSING ON PARENTING IN COUPLES WITH MARITAL RELATIONSHIP PROBLEMS}

\begin{abstract}
Marital relationship problems can affect the emergence of parenting problems. Relationship problem in parents will interfere parenting pattern and later could cause some problems such as psychopathology, behavioral disorder and academic decline. This qualitative case study and application of transactional analysis module on couples with marital relationship problem, focusing in parenting, involving three couples. The result showed in the transacional analysis psychotherapy implementation with couple therapy setting two clients could attend and finished the session, while one client did not complete the psychotherapy process. There was improvement in parenting pattern on two clients who finished the transactional analysis psychotherapy process. The improvement in parenting pattern along with improvement in couple's relationship. This is due to more in our spare time, love and affection for the children. To be concluded application of transactional analysis on couples with marital relationship problem could improve relationship, increase intimacy, and improve psychopathology. Improvement of marriage relationship can improve parenting pattern.
\end{abstract}

Keywords: marital relationship, parenting, psychopathology, transactional analysis

Departmen IImu Kedokteran Jiwa, Fakultas Kedokteran, Universitas Brawijaya

Deparmen IImu Kedokteran Jiwa, Fakultas Kedokteran, Universitas Sebelas Maret

E-mail: drdsyudhantara.fk@ub.ac.id 


\section{Pendahuluan}

Masalah relasi perkawinan terjadi pada $8,5 \%$ pada populasi umum dan $24,5 \%$ pasangan dengan gangguan psikiatri. Tingkat perceraian pada pasangan dengan masalah relasi lebih tinggi daripada pasangan yang tanpa masalah relasi. ${ }^{1}$ Data Badan Kependudukan dan Keluarga Berencana Nasional pada tahun 2010 menunjukkan bahwa terjadi 285.184 kasus perceraian. Alasan utama dari perceraian tersebutadalah adanya ketidakharmonisan, yaitu sebesar $70 \%{ }^{2}$ Masalah relasi dalam perkawinan merupakan salah satu bentuk dari psikopatologi keluarga. Hal ini dapat menyebabkan munculnya psikopatologi dalam keluarga. Kehidupan perkawinan yang patologis menyebabkan gangguan keseimbangan dalam lingkungan keluarga, salah satunya dapat mempengaruhi pola pengasuhan anak. ${ }^{3}$

Orangtua dengan masalah relasi akan menyebabkan gangguan pada pola asuh anak yang kemudian dapat menyebabkan beberapa masalah pada anak seperti psikopatologi, gangguan perilaku, dan penurunan akademik. Masalah relasi pada orangtua akan bertimbal-balik dengan munculnya gangguan pada anak. ${ }^{4}$

Studi ini menggunakan aplikasi psikoterapi analisis transaksional untuk mengatasi psikopatologi dan memperbaiki relasi pasangan. Dengan adanya relasi pasangan dan komunikasi pasangan yang lebih baik maka diharapkan terjadi perbaikan pola asuh anak.

Masalah relasi pasangan dalam The Diagnostic and Statistical Manual of Mental Disorders, IV-Text Revision (DSM-IV TR) dijelaskan sebagai pola interaksi antara pasangan atau partner yang ditandai oleh komunikasi negatif (seperti mengkritisi pasangan), komunikasi yang terdistorsi (seperti harapan yang berlebihan), atau tidak ada komunikasi (seperti penarikan diri) yang berhubungan dengan gangguan klinis signifikan pada fungsi individu atau keluarga atau berkembangnya gejala pada satu atau kedua pasangan. ${ }^{5}$

Psikopatologi dalam bidang psikiatri dapat diartikan sebagai asal-usul gangguan mental, tentang bagaimana hal tersebut berkembang dan gejala yang timbul. ${ }^{6}$ Psikopatologi atau perilaku disfungsional juga diartikan sebagai asal-usul perilaku abnormal. ${ }^{7}$ Psikopatologi juga merujuk pada abnormalitas, disfungsi, gangguan jiwa, atau psikopatologi dalam keluarga yang bermanifestasi dalam fungsi perilaku, interpersonal, emosional, kognitif, dan psikofisiologis. ${ }^{3}$ Psikopatologi dapat dinilai dengan berbagai macam instrumen. Salah satu instrumen yang digunakan adalah Symptoms Check List-90 (SCL-90). ${ }^{8}$

Eric Berne mengenalkan teori psikologi sosial yaitu analisis transaksional (AT) pada tahun 1950-an. Selanjutnya AT ini menjadi salah satu pendekatan psikoterapetik untuk masalah relasi. ${ }^{9}$ AT terdiri atas teori tentang kepribadian manusia dan sistem yang memungkinkan perbaikan relasi manusia. ${ }^{10}$ AT merupakan pendekatan psikoterapi yang terdiri dari banyak segi. Berne menekankan pentingnya komunikasi yang merupakan aspek utama dari AT. Selain sebagai sebuah teori psikoterapi, AT mengintegrasikan dinamik intrapsikis dengan perilaku seseorang sebagai landasannya dengan menekankan pada pendekatan eksistensial humanistik. ${ }^{11}$

Dalam konsep AT dikenal empat tahap kesembuhan, yaitu: (1) kontrol sosial; (2) penyembuhan gejala; (3) penyembuhan transferensi; dan (4) penyembuhan naskah atau otonomi.12 Penerapan analisis transaksional memberikan hasil yang baik. Sejak dipelopori oleh Eric Berne ${ }^{9}$, AT telah banyak diteliti dan menunjukkan keefektivan psikoterapi tersebut.13 AT efektif untuk mengatasi gangguan cemas dan depresi. .4, $15^{15}$ 
Terapi pasangan menggunakan pendekatan perilaku untuk mengatasi beragam masalah yang muncul pada pasangan. Masalah yang dimaksud tidak hanya yang berhubungan dengan relasi antar pasangan namun juga adanya psikopatologi pada masing-masing individu pada pasangan tersebut. Indikasi utama dari terapi pasangan adalah munculnya masalah relasi pada pasangan. Masalah relasi tidak dapat diselesaikan sendiri atau kedua pasangan mengalami kesulitan untuk mencari solusi atas masalah relasi yang dihadapinya. Tujuan dari terapi pasangan adalah tercapainya relasi yang memuaskan bagi kedua pasangan. Empat variabel kunci yang digunakan sebagai faktor prediktif dalam terapi pasangan meliputi kedekatan seksual, kedekatan fisik dan nonverbal, kedekatan emosional, dan kedekatan operasional. ${ }^{16}$

Pengasuhan (pola asuh) anak atau parenting dapat diartikan sebagai fungsi keluarga atau ketrampilan orangtua dan keluarga di sekitarnya dalam pengasuhan anak. ${ }^{17}$ Pola asuh anak dibagi menjadi beberapa tipe yaitu otoritatif, otoritarian, indulgen, dan uninvolved. Pola asuh ini berdasarkan atas dukungan parental dan kontrol parental. Dukungan parental merujuk pada kualitas afeksi yang berhubungan dengan kehangatan, penerimaan, dan keterlibatan dalam kehidupan anak. Kontrol parental tampak dalam kontrol orangtua terhadap perilaku anak dan pengawasan sehari-hari terhadap anak. ${ }^{18}$

Orangtua yang otoritatif memberikan iklim demokratik dengan dukungan yang tinggi dan kontrol parental. Orangtua yang otoritarian memberikan kontrol parental yang tinggi tanpa dukungan parental yang cukup, sehingga dianggap penuntut dan tegas. Pada orang tua dengan pola asuh indulgen, orangtua permisif dan memberikan dukungan parental yang berlebihan dan kurang dalam kontrol parental. Orangtua yang uninvolved cenderung tidak ada dukungan dan kontrol parental dan dalam hal ini juga mencakup penelantaran pada anak. ${ }^{17}$

\section{Bahan dan Metode}

Penelitian kualitatif ini berbentuk studi kasus dan mengaplikasi modul psikoterapi analisis transaksional pada pasangan dengan masalah relasi perkawinan berfokus pada pengasuhan anak. Instrumen penelitian yang digunakan yaitu penulis sendiri, lembar data isian demografi, lembar informed consent, lembar Symptoms Check List-90 (SCL-90), kuisioner analisis transaksional, modul psikoterapi analisis transaksional, checklist pelaksanaan sesi terapi sesuai modul psikoterapi analisis transaksional, kartu analisis egostate dan transaksi dari AATD, lembar penilaian pengetahuan egostate dan transaksi AATD, lembar egogram, verbatim, dan alat dokumentasi.

Pengambilan subjek dilakukan secara purposive sampling. Subjek penelitian adalah pasangan yang mengalami masalah relasi perkawinan yang menjalani rawat jalan di Poliklinik Psikiatri RSUD dr. Moewardi Surakarta yang memenuhi kriteria inklusi dan eksklusi pada periode Mei-Juni 2015. Kriteria inklusi sebagai berikut: (1) Pasangan yang mengalami masalah relasi perkawinan yang menjalani rawat jalan di Poliklinik Psikiatri RSUD dr. Moewardi Surakarta; (2) Usia 20-40 tahun; (3) Bisa membaca dan menulis; (4) Pendidikan minimal SMA; (5) Bersedia menjadi klien penelitian dibuktikan dengan menandatangani suratpersetujuan penelitian (informed consent). Kriteria Eksklusi pada penelitian ini adalah adanya salah satu atau kedua anggota pasangan yang menderita gangguan jiwa berat (psikotik).

Metode pengumpulan data dilakukan dengan wawancara, observasi, partisipasi aktif, dan dokumentasi terhadap klien penelitian sebelum, selama, dan setelah menjalani proses psikoterapi Analisis Transaksional. Sesi intervensi dilakukan 8 
sesi dengan durasi 60-90 menit setiap pertemuan. Analisis data dilakukan dengan mengacu pada metode perbandingan tetap (constant comperative method) mencakup reduksi data, kategorisasi data, sintesis data, dan interpretasi data. Penyajian data proses dan hasil terapi dalam bentuk data display yang berupa verbatim, grafik, dan matriks.
Hasil

Intervensi psikoterapetik dilakukan dengan menggunakan pedoman modul psikoterapi analisis transaksional pada pasangan dengan masalah relasi perkawinan berfokus pada pengasuhan anakini dilakukan pada 3 pasangan. Karakteristik subjek tampak dalam Tabel 1.

Tabel 1. Karakteristik awal klien

\begin{tabular}{|c|c|c|c|}
\hline Karakteristik & Kasus I & Kasus II & Kasus III \\
\hline \multirow[t]{5}{*}{ Suami } & Usia : 32 tahun & Usia : 53 tahun & Usia : 33 tahun \\
\hline & $\begin{array}{l}\text { Jenis kelamin : Laki- } \\
\text { laki }\end{array}$ & Jenis kelamin : Laki-laki & Jenis kelamin : Laki-laki \\
\hline & Pendidikan : SMA & Pendidikan : SMA & Pendidikan : SMA \\
\hline & Agama : Islam & Agama : Islam & Agama : Islam \\
\hline & Pekerjaan : Swasta & Pekerjaan : Swasta & Pekerjaan : Karyawan \\
\hline \multirow[t]{5}{*}{ Istri } & Usia : 24 tahun & Usia : 38 tahun & Usia : 30 tahun \\
\hline & $\begin{array}{l}\text { Jenis kelamin : } \\
\text { Perempuan }\end{array}$ & Jenis kelamin : Perempuan & Jenis kelamin : Perempuan \\
\hline & Pendidikan : S1 & Pendidikan : S1 & Pendidikan : SMA \\
\hline & Agama : Islam & Agama : Islam & Agama : Islam \\
\hline & $\begin{array}{l}\text { Pekerjaan : Pegawai } \\
\text { Kantor }\end{array}$ & $\begin{array}{l}\text { Pekerjaan : Ibu Rumah } \\
\text { Tangga }\end{array}$ & Pekerjaan : Buruh jahit \\
\hline $\begin{array}{l}\text { Usia } \\
\text { Pernikahan }\end{array}$ & 5 tahun & 9 tahun & 9 tahun \\
\hline \multicolumn{4}{|l|}{ Status } \\
\hline Ekonomi & Menengah ke atas & Menengah ke atas & Menengah ke bawah \\
\hline $\begin{array}{l}\text { Psikopatologi } \\
\text { (Skor T pada } \\
\text { SCL-90) }\end{array}$ & $\begin{array}{l}\text { Somatisasi }(75) \text {, } \\
\text { cemas }(62.5) \text {, depresi } \\
(63.4)\end{array}$ & $\begin{array}{l}\text { Somatisasi (37.5), obsesif } \\
\text { kompulsif }(40) \text {, cemas (37.5) }\end{array}$ & $\begin{array}{l}\text { Somatisasi (75), cemas } \\
(87.5) \text {, ansietas fobik (71.4) }\end{array}$ \\
\hline \multirow{2}{*}{$\begin{array}{l}\text { Ciri } \\
\text { kepribadian }\end{array}$} & Klien: Ambang & Klien: Narsisistik & Klien: Cemas Menghindar \\
\hline & Pasangan: Histrionik & Pasangan: Histrionik & Pasangan: Anankastik \\
\hline Diagnosis & $\begin{array}{l}\text { Gangguan } \\
\text { Somatisasi }\end{array}$ & $\begin{array}{l}\text { Gangguan mental dan } \\
\text { perilaku akibat penggunaan } \\
\text { zat multipel dan } \\
\text { penggunaan zat psikoakif } \\
\text { lainnya sindroma } \\
\text { ketergantungan kini } \\
\text { ketergantungan aktif }\end{array}$ & $\begin{array}{l}\text { Gangguan campuran } \\
\text { cemas dan depresi }\end{array}$ \\
\hline \multirow[t]{2}{*}{ Psikofarmaka } & & Clozapine $0-0-25 \mathrm{mg}$ & \\
\hline & Fluoxetine $20 \mathrm{mg}-0-0$ & Clobazam 0-0-5mg & Fluoxetine $20 \mathrm{mg}-0-0$ \\
\hline Anak & 1 orang usia 5 tahun & $\begin{array}{l}3 \text { orang anak: usia } 15 \text { tahun, } \\
13 \text { tahun, dan } 8 \text { tahun }\end{array}$ & 1 orang usia 7 tahun \\
\hline
\end{tabular}




\section{Gambaran Kasus}

Pada Tabel 2 akan ditampilkan gambaran rangkuman temuan kasus yang meliputi usia pernikahan, ciri kepribadian, faktor kerentanan, faktor pencetus dan stresor, kecenderungan egostate, transaksi, dan stroke.

Pada kasus I, suami lebih banyak melakukan pengasuhan anak dibandingkan dengan istri. Suami mempunyai waktu yang lebih banyak di rumah dibandingkan dengan istri yang lebih banyak di kantor sehingga anak lebih dekat dengan suami. Istri cenderung untuk menyerahkan pengasuhan anak kepada suaminya. Masalah relasi yang timbul pada pasangan salah satunya dipengaruhi oleh perbedaan dalam pola asuh anak. Suami cenderung permisif dan memiliki pola asuh indulgen sedangkan istri memiliki kecenderungan untuk uninvolved dalam pengasuhan anak. Perbedaan pola asuh ini menyebabkan anak tampak menjadi anak yang penuntut dan cenderung untuk menampakkan perilaku emosional. Pasangan juga mengeluh kalau terkadang anaknya sulit untuk diatur.

Pada kasus II, pasangan memiliki tiga orang anak. Dua orang anak dari suami dan satu anak dari istri, mereka dari pernikahan sebelumnya. Terdapat perbedaan pola asuh yang diberikan oleh pasangan kepada anaknya. Suami cenderung indulgen sedangkan istri cenderung untuk otoritarian. Perbedaan pola asuh ini sering memberikan masalah relasi orangtua-anak. Anak pertama yang beranjak remaja cenderung untuk selalu bertentangan dengan ibunya.

Pada kasus III, pasangan hanya mempunyai satu orang anak dengan kelainan distrofia otot. Sejak anaknya sakit pasangan selalu memperhatikan anaknya dan cenderung menuruti semua keinginan anaknya. Anaknya menjadi anak yang manja dan cenderung meminta dituruti semua keinginannya. Anaknya sering merengek dan menangis jika keinginannya tidak dipenuhi.

\section{Proses Terapi}

Proses terapi diawali dan dilakukan berdasarkan kontrak terapi yang telah disepakati di awal sesi terapi. Proses terapi berlangsung sesuai dengan modul dan dengan beberapa modifikasi disesuaikan dengan kondisi nyata yang dihadapi dalam terapi. Pada kasus I dan kasus I| terapi dilakukan hingga semua klien menyelesaikan proses terapi. Pada kasus III, klien awalnya cukup antusias dalam menjalani psikoterapi dan bersedia untuk menandatangani kontrak terapi. Tahap awal terapi telah dilakukan namun selanjutnya klien belum bisa melanjutkan terapi yang dilakukan. Beberapa hal yang menjadi catatan penyebab keluarnya klien dari proses terapi terutama adalah faktor ekonomi.

Proses terapi didokumentasikan dengan menggunakan beberapa media perekaman seperti video dan rekaman suara. Proses terapi juga menggunakan blanko yang diisi oleh penulis dan klien seperti kontrak terapi, lembar egogram, dan lembar stroke. Langkah terapi yang telah didokumentasikan dinilai oleh ahli untuk melihat validitas proses terapi yang dilakukan. Proses terapi juga dinilai sendiri oleh penulis dengan menggunakan daftar tilik diri dan juga dinilai oleh pengamat bebas. Pada proses terapi ini pengamatan dilakukan oleh rekan residen psikiatri. Berdasarkan atas penilaian ahli (psikiater senior) didapatkan proses terapi telah dilakukan dengan baik. Berdasarkan daftar tilik yang dinilai oleh penulis maka semua langkah dan tahapan telah dilakukan disertai beberapa modifikasi yang disesuaikan dengan kondisi pada saat terapi. Modifikasi yang dilakukan tidak mengubah isi dan tujuan terapi yang dilakukan. 
Tabel 2. Rangkuman temuan pada kasus

\begin{tabular}{|c|c|c|c|}
\hline Variabel & Kasus I & Kasus II & Kasus III \\
\hline Usia pernikahan & 5 tahun & 9 tahun & 9 tahun \\
\hline \multicolumn{4}{|l|}{ Ciri kepribadian } \\
\hline - Suami & Ambang & Narsisitik & Cemas menghindar \\
\hline \multirow[t]{2}{*}{$\cdot$ Istri } & Histrionik & Histrionik & Anankastik \\
\hline & $\begin{array}{l}\text { - Perbedaan usia yang } \\
\text { cukup besar pada } \\
\text { pasangan }\end{array}$ & $\begin{array}{l}\text { - Riwayat perceraian } \\
\text { pada kedua pasangan }\end{array}$ & \\
\hline \multirow[t]{2}{*}{ Faktor kerentanan } & $\begin{array}{l}\text { - Riwayat perceraian } \\
\text { pada keluarga }\end{array}$ & $\begin{array}{l}\text { Riwayat bergonta- } \\
\text { ganti pasangan pada } \\
\text { kedua pasangan }\end{array}$ & Masalah ekonomi \\
\hline & -Kecemburuan pasangan & $\begin{array}{l}\text { - Perbedaan usia yang } \\
\text { cukup besar pada } \\
\text { pasangan } \\
\text { ·Kecemburuan } \\
\text { pasangan }\end{array}$ & \\
\hline \multirow{3}{*}{$\begin{array}{l}\text { Faktor pencetus dan } \\
\text { stresor }\end{array}$} & $\begin{array}{l}\text { - Kekerasan dalam } \\
\text { rumah tangga }\end{array}$ & $\begin{array}{l}\text {-Kekerasan dalam } \\
\text { rumah tangga }\end{array}$ & \\
\hline & Situasi triangular & $\begin{array}{l}\text { Pernikahan di usia } \\
\text { yang bermasalah }\end{array}$ & 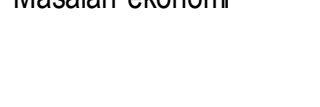 \\
\hline & $\begin{array}{l}\text {-Pasangan pengguna } \\
\text { alkohol dan NAPZA }\end{array}$ & $\begin{array}{l}\text { - Pasangan pengguna } \\
\text { alkohol dan NAPZA }\end{array}$ & \\
\hline \multicolumn{4}{|l|}{$\begin{array}{l}\text { Kecenderungan Struktur } \\
\text { kepribadian menurut AT } \\
\text { - Suami }\end{array}$} \\
\hline \multirow[t]{2}{*}{$\cdot$ Istri } & $\mathrm{KB}$ tinggi, $\mathrm{D}$ rendah & OK tinggi, $\mathrm{D}$ rendah & KS tinggi, D rendah \\
\hline & $\begin{array}{l}\text { OK tinggi, KB tinggi, } \\
\text { D rendah }\end{array}$ & OK tinggi, $\mathrm{D}$ rendah & OP tinggi, $\mathrm{D}$ rendah \\
\hline Transaksi menurut AT & Silang & Silang & Silang \\
\hline Stroke & Negatif, tidak ada stroke & $\begin{array}{l}\text { Negatif, tidak ada } \\
\text { stroke }\end{array}$ & Negatif, tidak ada stroke \\
\hline
\end{tabular}

Penilaian Skala Klinis dan Keberhasilan Terapi

Pada pelaksanaan psikoterapi analisis transaksional dengan setting terapi pasangan ini, dua klien dapat mengikuti hingga selesai sedangkan satu klien tidak menyelesaikan proses psikoterapi. Hasil proses psikoterapi pada dua klien dapat dilihat pada Tabel 3 . 
Tabel 3. Rangkuman evaluasi hasil terapi

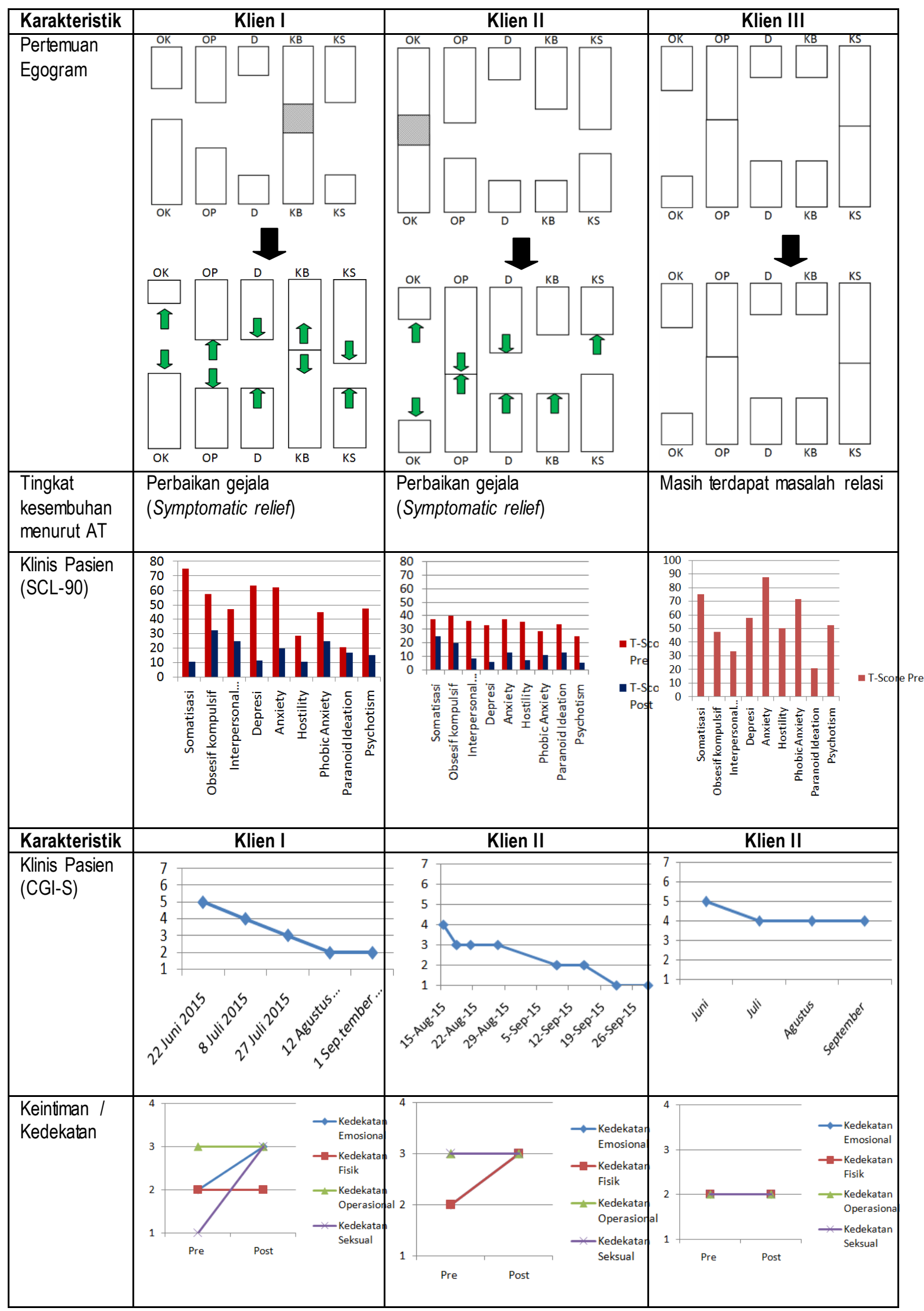


Dari sudut pandang pola asuh anak diketahui ada perbedaan. Pada klien I, dengan perbaikan relasi, istri menjadi lebih banyak terlibat dalam pengasuhan anak. Pasangan pada kasus I lebih banyak membuat kesepakatan tentang apa yang akan dilakukan pada anaknya. Kedua pasangan saat ini lebih banyak menghabiskan waktu dengan anak di luar jam kerja dan tidak sibuk dengan kegiatan masing-masing lagi. Suami sudah tidak selalu menuruti permintaan anaknya. Dengan kehadiran kedua orangtua, anak pasien menjadi tidak sering merengek lagi dan tampak tidak terlalu penuntut dan emosional dibandingkan sebelumnya. Pada kasus II, masalah relasi pada pengasuhan anak lebih banyak terjadi pada istri dan anak pertamanya. Setelah mengikuti sesi terapi, terjadi perbaikan hubungan antara istri dan anak pertamanya, yaitu timbul kedekatan yang lebih antara istri dan anak pertamanya. Suami cenderung tidak lagi memenuhi segala permintaan anaknya. Pada kasus III, belum terjadi perbedaan dalam pengasuhan anak.

\section{Pembahasan}

Penelitian ini berfokus pada perbaikan masalah relasi yang akan turut memperbaiki pola asuh anak. Pada kasus I dan II terjadi perbaikan pada masalah relasi dan perbaikan psikopatologi. Perbaikan gejala klinis pada klien merupakan hasil kombinasi antara psikoterapi dan psikofarmaka. Psikoterapi dan psikofarmaka secara bebas mempengaruhi perbaikan pada psikopatologi pasien. Kombinasi terapi antara keduanya meningkatkan keefektivan keduanya. Hal ini tampak dari studi yang dilakukan oleh Cuijpers et al., (2014) yang menunjukkan terapi kombinasi antidepresan dan psikoterapi memiliki keefektivan yang lebih baik daripada salah satu saja. 19,20

Perbaikan masalah relasi dan perbaikan komunikasi antara pasangan yang terjadi menyebabkan perbaikan pada pola asuh anak. Pada kasus I, orangtua menjadi lebih banyak menunjukkan kasih sayang dan afeksi kepada anak. Hal ini tampak dalam banyaknya waktu yang dihabiskan dengan anak dan beberapa hal yang disepakati bersama oleh pasangan sehingga tampak pada anak yang menjadi kurang emosional. Suami tidaklagi terlalu permisif dan menuruti semua permintaan anaknya, sedangkan istrinya menjadi tidak terlalu pemarah dan bisa menghabiskan banyak waktu dengan anak. Pada kasus II, terjadi perbaikan hubungan antara istri dengan anak pertamanya. Istri tidak terlalu menuntut dan lebih perhatian kepada anaknya. Suami menjadi tidak terlalu menuruti permintaan anaknya dan mendiskusikan banyak hal terkait pengasuhan anak sehingga tidak salah satu saja yang mendominasi.

Pola asuh anak merupakan pola yang sangat menentukan bagi masa depan anak. Hal ini berkaitan dengan pencapaian akademik, optimisme, kepercayaan diri, motivasi, perilaku eksternalisasi, dan masalah perhatian. ${ }^{21}$ Anak dengan orangtua yang yang memiliki masalah marital mempunyai risiko yang lebih besar untuk mengalami permasalahan di atas. ${ }^{22}$ Pola asuh anak secara konsisten menunjukkan berhubungan dengan psikopatologi, gangguan perilaku dan performa akademik. ${ }^{23}$ Masalah relasi orangtua menyebabkan gangguan pengasuhan anak yang dapat memberikan dampak kepada anak berupa rendahnya prestasi akademik dan munculnya gangguan perilaku. ${ }^{24}$ Studi yang dilakukan oleh Siffert et al. (2012) menunjukkan bahwa terdapat hubungan secara tidak langsung antara konflik marital dengan munculnya rasa rendah diri pada remaja. ${ }^{25}$

Timbulnya masalah relasi dalam perkawinan dapat menyebabkan masalah perilaku pada anak. Dengan perbaikan masalah relasi ini maka terjadi perbaikan pada masalah perilaku anak. ${ }^{4}$ Dengan 
perbaikan komunikasi dan meningkatnya keintiman (kedekatan) akan berpengaruh pada pola asuh anak. Meningkatnya keintiman akan menimbulkan kepuasan marital. Kepuasan marital merupakan faktor prediktor penting dalam pola asuh anak Masalah atau konflik parental dan konflik orangtua-anak berhubungan dengan gangguan perilaku, emosional, sosial, dan masalah kesehatan anak. Analisis transaksional juga efektif digunakan dalam memperbaiki hubungan negatif orangtuaanak pada keluarga alkoholik. ${ }^{26}$

Keterbatasan dalam studi ini adalah: (1) Penulis mengalami kesulitan dalam pencarian subjek studi dikarenakan pada beberapa klien gangguan jiwa dengan masalah relasi pasangan yang periksa ke poli jiwa, salah satu atau kedua pasangan tidak bersedia untuk hadir dalam sesi psikoterapi dengan setting terapi pasangan yang akan dilakukan; (2) Semua klien yang periksa ke poli jiwa adalah laki-laki atau suami dan belum ada subjek yang perempuan sehingga belum diketahui bagaimana proses terapi pada klien perempuan; (3) Pada klien dengan masalah pencetus utama berupa faktor ekonomi belum dapat mengikuti proses terapi sehingga belum bisa diambil kesimpulan.

\section{Kesimpulan}

Hasil studi ini menunjukkan aplikasi modul psikoterapi analisis transaksional pada pasangan dengan masalah relasi perkawinan yang memeriksakan diri ke Poliklinik Jiwa RSUD dr. Moewardi Surakarta dapat memperbaiki relasi, menambah keintiman pasangan, dan memperbaiki psikopatologi. Perbaikan pada relasi pasangan menyebabkan perbaikan pola asuh dan relasi antara orang tua anak.

\section{Saran}

Modul psikoterapi analisis transaksional pada pasangan dengan masalah relasi perkawinan yang dipakai dalam studi ini dapat digunakan sebagai penuntun analisis transaksional untuk mengatasi psikopatologi pada pasangan yang mengalami masalah relasi dalam perkawinan. Modul tersebut juga dapat diaplikasikan untuk memperbaiki gangguan pengasuhan anak yang didasari dari masalah perkawinan tersebut.

\section{Daftar Pustaka}

1. Chambliss RB dan McLeer SV. Relational Problems. In: Sadock BJ, Sadock VA, Ruiz P. Kaplan \& Sadock's Comprehensive Textbook of Psychiatry. $9^{\text {th }}$ Edition. Philadelphia: Lippincott Williams \& Wilkins. 2009. p 2469-2478.

2. Badan Kependudukan dan Keluarga Berencana Nasional. Angka Perceraian di Indonesia Tertinggi di Asia-Pasifik. http://www. bkkbn. go. id/NiewBerita. Aspx?BeritalD=967. Diakses pada 3 Maret 2015

3. Kumar $P$ dan Tiwari SC. Family and Psychopathology: An Overview Series-1: Children and Adults. Delhi Psychiatry Journal. 2008; $11(2): 140-149$.

4. Neece CL, Green SA, dan Baker BL. Parenting Stress and Child Behavior Problems: A Transactional Relationship Across Time. Am J Intellect Dev Disabil. 2012; 117(1): 48-66.

5. American Psychiatric Association. Relational Problem. Dalam: Diagnostic and Statistical Manual of Mental Disorders. $4^{\text {th }}$ Edition, Text Revision (DSM-IV-TR). Washington: American Psychiatric Publishing. 2009. p 737.

6. Rudd K. Understanding Psychopathology. http://www.Sagepub.Com/upmdata/58633 Rudd. Pdf. Diakses pada 19 February 2015. 
7. Goldenberg H dan Goldenberg I. Family Therapy: An Overview. $8^{\text {th }}$ Edition. Belmont: Brooks/Cole; 2013.

8. Adam RL dan Culbertson JL. Personality Assessment: Adults and Children. Dalam: Sadock BJ, Sadock VA, Ruiz P. Kaplan \& Sadock's Comprehensive Textbook of Psychiatry. 9 $9^{\text {th }}$ Edition. Philadelphia: LippincottWilliams \& Wilkins. 2009. p 951973.

9. Johnsson R. Transactional Analysis as Psychotherapy Method - A Discourse Analytic Study. IJTAR. 2011; 2(2): 3-18.

10. Aldoghan M. Transactional Analysis and its Intrigue in Saudi Arabian Organizations IJBSS. 2014; 5: 8.

11. Clarkson P. Treatment Planning. In: Transactional Analysis Psychotherapy. London: Routledge. 1992. p 90-147.

12. Stewart I dan Tilney T. Analisis Transaksional. Dalam: Palmer S. Konselling dan Psikoterapi. Yogyakarta: Pustaka Pelajar. 2010. p 569-594.

13. Ohlsson T. Scientific Evidence Base for Transactional Analysis in the Year 2010. IJTAR. 2010; 1(1): $12-23$.

14. van Rijn B, Wild C, Fowlie $H$, Sills $C$, van Beekum S. Impact of Transactional Analysis Psychotherapy Training on Self Awareness and Ability for Contact. IJTAR. January 2011; 2(1): 16-24.

15. Widdowson M. The Process and Outcome of Transactional Analysis Psychotherapy for the Treatment of Depression: An Adjudicated Case Series. [Disertation]. University of Leicester Leicester. 2013.

16. Crowe M dan Ridley J. Therapy with Couples, a behavioural-systems approach to couple relationship and sexual problems. 2 ${ }^{\text {nd }}$ Edition. Oxford: Blackwell Sciennce Ltd. 2000.

17. Huver RME, Otten R, de Vries H, Engels RCME. Personality and Parenting Style in Parents of Adolescents. J Adolescence. 2010; 33: 395-402.
18. Stattin H dan Kerr M. Parental monitoring: a reinterpretation. Child Dev. 2000; 71: 1072-1085.

19. Cuijpers P, Sijbrandij M, Koole SL, Andersson G, Beekman AT, Reynolds III CF. Adding Psychotherapy to Antidepressant Medication in Depression and Anxiety Disorders: A Meta-Analysis. World Psychiatry. 2014;13:56-67.

20. Frank E, Novick D, Kupfer DJ. Antidepressants and psychotherapy: a clinical research review. Dialogues Clin Neurosci. 2005;7:263-272.

21. Kordi A dan Baharudin R. Parenting Attitude and Style and Its Effect on Children's School Achievements. Int J Psychol Stud. 2010; 2(2): 217-222.

22. Cummings EM dan Schatz JN. Family Conflict, Emotional Security, and Child Development: Translating Research Findings into a Prevention Program for Community Families. Clin Child Fam Psychol Rev. 2012; 15(1): 14-27.

23. Turner EA, Chandler M, Heffer RW. The Influence of Parenting Styles, AchievementMotivation, and Self-Efficacy on Academic Performance in College Students. J Coll Stud Dev. 2009; 50(3): 337-346.

24. Galluzzo DM. The academic and social impact of divorce on early childhood students in school. [Tesis]. 2012. Paper 38.http://hdl. Handle. Net/2047/d20002769

25. Siffert A, Schwarz B, Stutz M. Marital Conflict and Early Adolescents' SelfEvaluation: The Role of Parenting Quality and Early Adolescents' Appraisals. J Youth Adolesc. 2012; 41(6): 749-763.

26. Eiden RD, Kenneth E. Leonard, Rick H. Hoyle, Felipa Chavez. A Transactional Model of Parent-Infant Interactions in Alcoholic Families.. Psychol Addict Behav. 2004 December ; 18(4): 350-361. 